\title{
BI liaison project update
}

\author{
By Carolyn Kirkendall \\ Project LOEX \\ Eastern Michigan University
}

\section{Programs, poster sessions, and publications.}

$\mathbf{O}$ ur Project continues to search for and publicize opportunities where academic librarians can become involved in other professional association meetings. Recent participation included Carroll Wetzel Wilkinson's paper at the Tenth Annual Meeting of the Association for Gerontology in Higher Education. Wilkinson is the chief circulation librarian at the West Virginia University Library, Downtown Campus. She spoke in February on "Partners in Instruction: Connecting Gerontologists and Librarians."

Last month, the Missouri Valley History Conference program agenda included these panelists: Laurene Zaporozhetz from the University of Oregon, on "Self-Service Online Bibliographic Databases"; Betsy Baker from Northwestern University Library, who moderated the panel; Harold Smith from the Park College Library in Missouri, who served as commentator; and Maureen Pastine, director of the San Jose State University Library, who spoke on "Using U.S. Government Publications in Women's Studies."

A proposal for a poster session to be held at the Annual Meeting of the American Association for the Advancement of Science in New York has been submitted. We're hoping that Joan Lippincott's proposal has been accepted. Joan is the head of reference at Cornell University's Mann Library. The abstract of her proposed May session reads:

Instruction in accessing online bibliographic databases via personal computers or office terminals. New user-friendly systems have been developed to enable individuals to search online bibliographic databases. Researchers, faculty, and students can now use personal computers or office terminals to retrieve the kinds of information tradi- tionally obtained through printed sources in the library. This session will present information on the instructional program offered by the Albert R. Mann Library at Cornell University. Faculty and students are taught to access bibliographic databases through the BRS After Dark system. The components of the class session, which include developing a search strategy, choosing databases, employing controlled vocabularies, and using Boolean operators will be highlighted. The objectives of the instruction session and an evaluation study of user satisfaction will be presented. Guidelines for establishing programs for the education of end users will be proposed.

One of the responsibilities of this Project is to serve as a clearinghouse for librarians interested in working with particular disciplines and associations. Mary Lou Goodyear from the Auraria Libraries in Denver is interested in hearing from other librarians who might be involved in the American Society for Public Administration activity. Susan Klimley from the Lamont-Doherty Geological Observatory Library reports on her participation with the Geoscience Information Society, which meets with the Geological Association of America. About 35 librarians and publishers attend the annual meetings of these groups. Our Liaison Project would also like to hear from any readers who are members of the American Association of Women in Psychology, which will meet this summer in Ann Arbor, Michigan.

We'd like to continue featuring announcements of articles written by librarians who publish in the journals of other associations. Please keep our colleagues up to date by relaying information to me when you write or read appropriate articles. For 
example, in the January 1984 issue of Teaching Sociology, see David B. Booth's report on "Studying Research Methods by Examining Changing Research Strategies." The article examines students' reactions to a methods course in which a key requirement is the use of journals to compare and interpret changes in research methods. Booth is a faculty member with the Department of Sociology and Anthropology at the University of Windsor. The course happily included librarian input.

Those of you interested in submitting items relating to online services might look for a copy of a new newsletter, SCOPE (Joseph Raben, Director, Paradigm Press, P.O. Box 1057, Osprey, FL 33559-1057). SCOPE stands for Scholarly Communication: Online Publishing and Education, and seems a good potential publishing vehicle to consider.

We've redesigned our traveling exhibit and will display it at ALA Annual Conference in Dallas this June, to show other ACRL and ALA members what has been available for them to use at meetings and faculty colloquia. I need your assistance! If you'd like to help out and staff the booth for an hour to promote the Liaison mission, please let me know. Please call the LOEX Clearinghouse at (313) 487-0168 any weekday morning. Now is also a good opportunity to thank all of you for contacting our Project during the past several years with offers to participate. Our Liaison Project appreciates your enthusiastic assistance and support.

\section{Johnson named librarian of the year}

Richard D. Johnson, director of libraries at State University College, Oneonta, New York, has been awarded the ACRL Academic or Research Librarian of the Year Award for 1984. The Association of College and Research Libraries and the Baker \& Taylor Company will present the award to Johnson on June 25 at the ACRL reception at Annual Conference in Dallas.

The award cites Johnson for his experience in public, technical, and administrative services at three institutions (Oneonta, the Clare-

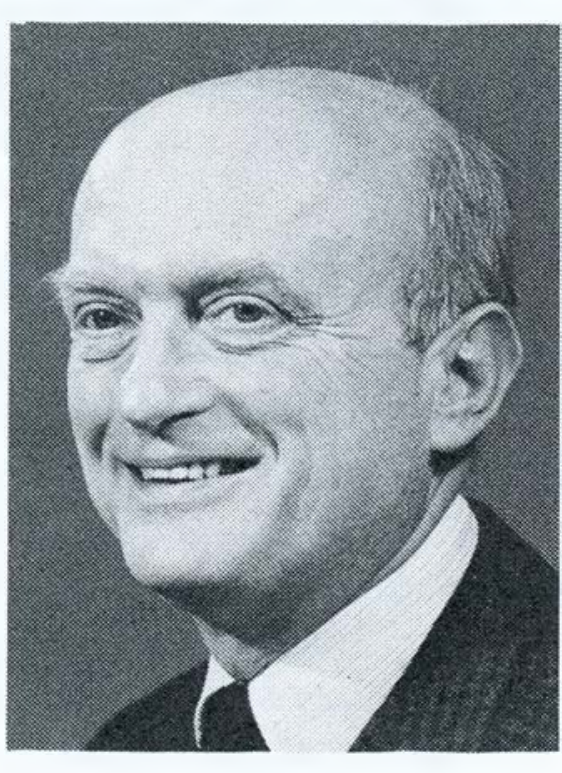

Richard D. Johnson mont Colleges, and Stanford University) and for a career that "embodies the range of activities and the high professional standards of the compleat librarian."

Johnson was also cited for his service as editor of College \& Research Libraries and California L $i$ brarian; as member of ACRL editorial boards and the Publications Committee; as acting editor $o^{-}$ Choice during a time of special need; and as chai: of a special committee that is preparing a third edi. tion of Books for College Libraries for publication.

The success of ACRL's First National Conference held in Boston in 1978 can largely be attributed to his generous and energetic efforts as chair of the Conference Program Committee. He was also co-editor of the proceedings for that conference, published as New Horizons for Academic Libraries by K.G. Saur, and served as consultant for the Second National Conference in Minneapolis in 1981.

Johnson has written the "Academic Libraries" chapter in the ALA Yearbook every year since 1976 and has been active in other ALA divisions, especially the Library Administration and Management Association and the Resources and Technical Services Division.

"Richard Johnson's professional accomplishments," the award citation reads, "have been complemented by his quiet and unassuming manner. While his knowledge and understanding in professional matters have been enriched by years of sound experience, his effectiveness has stemmed in large measure from giving without expecting praise and serving without seeking fame."

The ACRL Academic or Research Librarian of the Year Award was established by ACRL and the Baker \& Taylor Company to recognize individual members of the library profession who have made outstanding national or international contributions to academic or research librarianship and library development. The award consists of $\$ 2,000$ and a citation.

Recipients of the award since its inception in 1978 have been: Keyes D. Metcalf and Robert B. Downs (1978); Henriette D. Avram and Frederick G. Kilgour (1979); Evan I. Farber (1980); Beverly P. Lynch (1981); William S. Budington (1982); and Richard M. Dougherty (1983).

\section{System users, take note}

Stephen R. Salmon, president of Carlyle Systems, Inc., would like to have information on any existing library automation systems not yet described in the open literature. He is working on a revision of his book, Library Automation Systems, published in 1975 by Marcel Dekker. You may contact him at Carlyle Systems, Inc., 600 Bancroft Way, Berkeley, CA 94710; (415) 843-3538. 


\section{Doctoral Dissertation Fellowship awarded}

Donald P. Gould, University of Southern California, has been granted a doctoral dissertation fellowship by ACRL and the Institute for Scientific Information. His proposed research is entitled: "An Examination of Levels of Work in Academic Library Technical Services Departments for the Purpose of Determining Levels of Work Performed According to Time-Stratified Systems Theory." The award consists of a citation and $\$ 1,000$ contributed by ISI and will be presented to him at the ALA Annual Conference in Dallas.

This is the second ACRL Doctoral Dissertation Fellowship to be granted. Last year's fellowship went to Stanton F. Biddle, a doctoral candidate at the University of California, Berkeley. The purpose of the fellowship is to foster research in aca- demic librarianship by encouraging and assisting doctoral students in the field with their dissertation research.

Recipients of the fellowship must be active doctoral students in the academic librarianship area in a degree-granting institution who have completed all their coursework and had their proposal accepted by the institution. The criteria for judging include the potential significance of the research, methodological validity, originality, clarity, and a convincing timetable.

Applications for next year's fellowship may be made to: Sandy Whiteley, Program Officer, ACRL/ALA, 50 East Huron St., Chicago, IL 60611. They must be received by December 1 , 1984, to be eligible.

\section{Books, libraries and culture: A call for papers}

The role and significance of graphic records in society is the focus of a call for papers for a national library history seminar scheduled in March 1985.

The call has been issued jointly by the Graduate School of Library and Information Science at the University of Texas, Austin, and the School of Library Science at the University of North Carolina, Chapel Hill. The two schools are sponsors of Library History Seminar VII, "Books, Libraries and Culture," to be held in March 1985 at Chapel Hill.

Anyone interested in submitting a paper to be read at the conference should send a prospectus of no more than 500 words to Donald G. Davis Jr., Associate Professor of Library and Information
Science, UT Austin, Box 7576, University Station, Austin, TX 78712. The deadline for submission is July 1, 1984.

Paper topics are not limited to chronological period, geographical region, type of library, or type of media. Subjects may include biographical studies, institutional development, collection efforts, cultural and socio-economic environments, literacy, reading, history of the profession, bibliographical history, comparative librarianship, sources for research, and teaching methods. Papers selected for presentation at the seminar will be published by the University of Texas Press.

\section{Visit a London library}

Within 50 miles of Piccadilly Circus in London is a huge concentration of library and information services: the British Library Reference Division, a great network of urban and rural public libraries, libraries in schools and institutes of higher education, government libraries, and special libraries. There are also five of the U.K. schools of library and information studies and the headquarters of the Library Association and Aslib.

The London and Home Counties Branch of the Library Association has offered to help American librarians wishing to visit libraries in this area, London and the Southeast of England. They will plan a program of library visits to suit the particu- lar interests of groups of librarians, library school students, and individual librarians.

No charge will be made for this service. A minimum of one month's notice must be given prior to your arrival. Be as specific as possible about not only the kind of library you wish to visit, but also the particular aspects of their services which interest you. In return they ask that you write a short, informal report on your experiences to help them assess their services.

For further information write: Eric Winter, 19, Cricketers Drive, Meopham, Kent DA13 0AX, England. 


\section{Section news}

-The Bibliographic Instruction Section's Education for Bibliographic Instruction Committee, in conjunction with the Teaching Methods Interest Group of ALISE, held a program at the ALISE Conference in Washington on January 5. Entitled "Education for Bibliographic Instruction," the program's goals were to: 1 ) initiate communication between ALISE and ACRL/BIS and encourage involvement between library school faculty and BI practitioners; 2) clarify the definition and components of education for $\mathrm{BI}$; and 3) demonstrate the importance of library schools offering the opportunity for BI education. Speakers included Betsy Baker (Northwestern), Joe Boissé (UC-Santa Barbara), Betsy Wilson (University of Illinois), and Anne Mathews (University of Denver).

Production of the first issue of the BIS Newsletter is underway. The newsletter will keep section members informed of section activities, projects, meetings, publications, and programs.

The BIS Research Committee is currently working on two projects: the identification of research on the impact of $\mathrm{BI}$ on reference activity; and the interpretation of BI statistics-how they are used and the ways in which statistics can be interpreted effectively and correctly.

- The Slavic and East European Studies Section's Committee for Continuing Education on Slavic Librarianship in North America has begun work on a handbook on book culture in the USSR and Eastern Europe. The project, expected to be ready in 1985, will cover publishing, libraries, and bibliography in those countries. There will be an international group of contributors.

- The Western European Specialists Section will be taking some initial steps toward a closer working relationship with the Council for European Studies. A resolution passed at the May 1983 Conference on West European Studies and North American Research Libraries urged WESS and the Council to "ensure that similar gatherings of librarians and researchers in the fields of Western European studies and its component disciplines be held at regular intervals of approximately three years."

WESS also expressed appreciation to the Smithsonian's Woodrow Wilson International Center for Scholars and to Center librarian Zdeněk David for the Scholar's Guide series which was termed "invaluable to researchers in European studies." The section also requested that ARL and the Library of Congress actively explore the process of cooperative distributed cataloging.

The WESS Publications Committee has announced completion of a descriptive directory of WESS members. The directory will be published as a supplement to the summer edition of the WESS Newsletter edited by Charles Fineman, Northwestern Univerrsity.

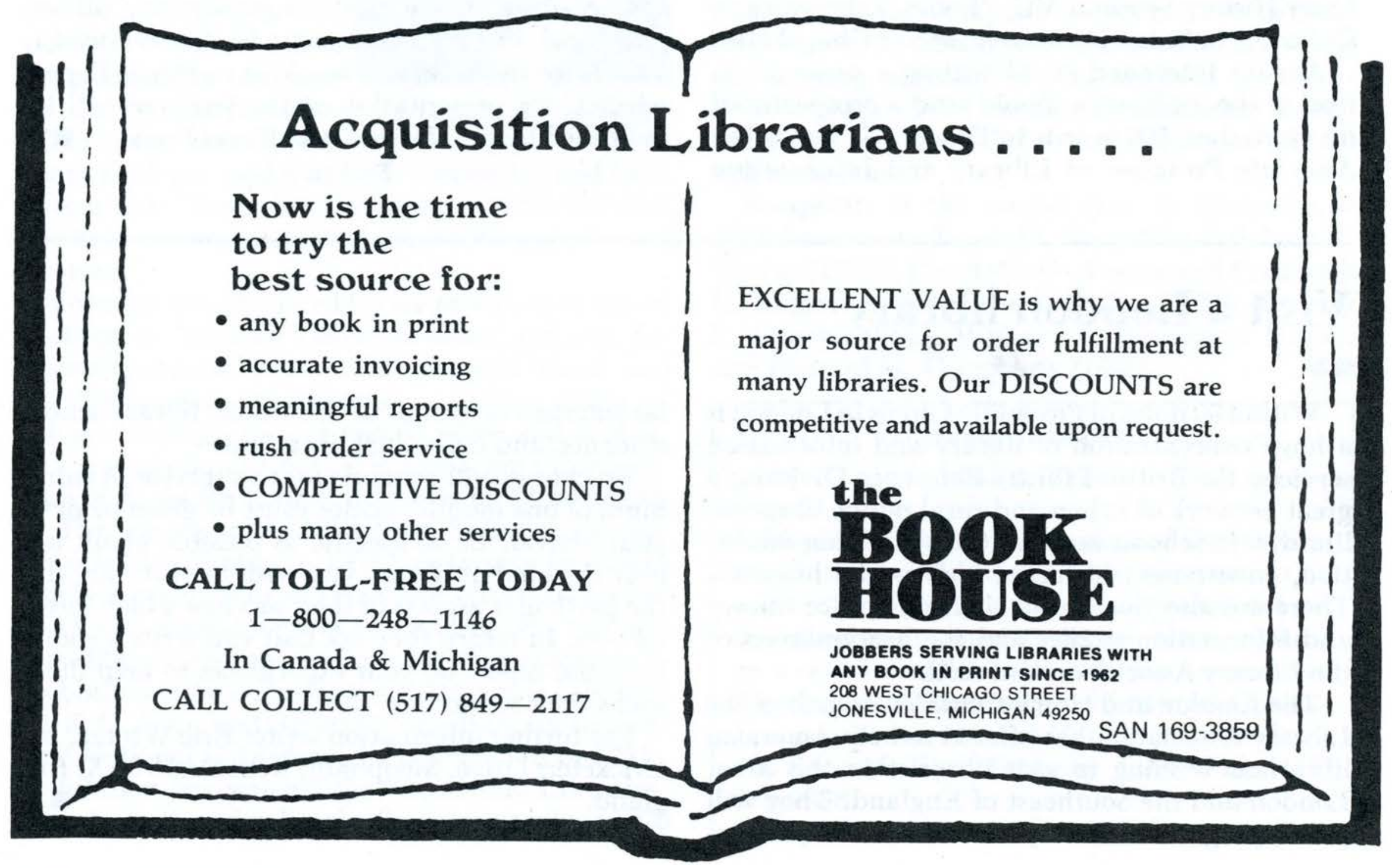




\section{Chapter news}

- The Eastern New York Chapter has published a directory of its members; arranged alphabetically and by institution. The chapter plans to update the directory either annually or bi-annually.

The chapter will hold its Spring Conference on May 4 at the State University of New York at Albany. The theme is "Human Dynamics: Recruitment, Ethics, Evaluation, and Other Personnel Issues." For more information, contact: Mary Osielski, University Library, SUNY-Albany, 1400 Washington Ave., Albany, NY 12222; (518) 457 7529.

- The Greater New York Metropolitan Area Chapter's Social Science and Humanities Database Users' Group held a workshop on March 7 at Bobst Library, New York University, on "PsycINFO: An Online Searching Workshop." Workshop coordinator was Caroline Gosling, user services associate for PsycINFO.

- The Nebraska Chapter will hold its Spring Meeting on April 20 at Bellevue College, Bellevue. Papers will be presented on the theme, "Computers: Cure-All or Snake Oil?" Contact: Tom Tollman, University Library, University of Nebraska at Omaha, 60th and Dodge, Omaha, NE 68182
- The New England Chapter held its Spring Conference at Brown University on March 29-30. The program examined the ways in which academic libraries can adapt to new trends in higher education. Speakers included Murray Martin, Richard Dougherty, Nancy Eaton, John Cole, Merrily Taylor, and Patricia Swanson.

- The New Jersey Chapter will hold two programs at the New Jersey Library Association Conference on April 25-26: "Myths/Realities of Academic Women Librarians," by Dee Garrison, Patricia Schuman, and Leigh Estabrook; and "Librarians in Search of Excellence," by Beverly Lynch. The chapter also held a program at Rider College on April 3 on "Implications of the New Jersey Library Network for Academic Librarians."

-The Wisconsin Chapter, the Wisconsin Association of Academic Libraries, will hold its first Leadership Conference on April 29-30 at the Midway Motor Lodge in Green Bay. Its goal will be to promote professional growth and WAAL organizational membership renewal.

The chapter has also started a newsletter, the ACRL/WAAL Newsletter, the first number of which premiered in January.

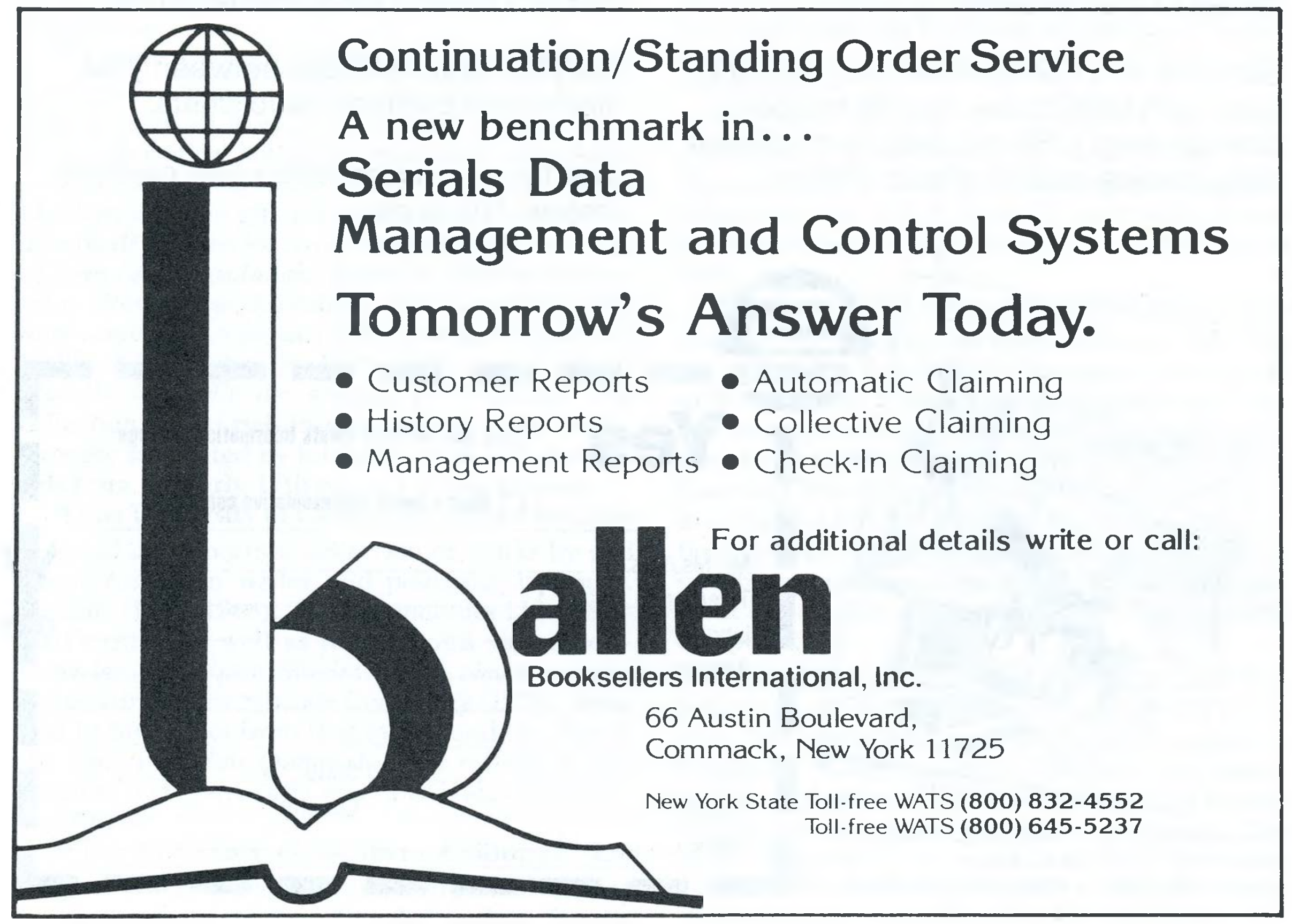




\section{DO YOU THINK THIS TO BE A FAIR QUESTION?}
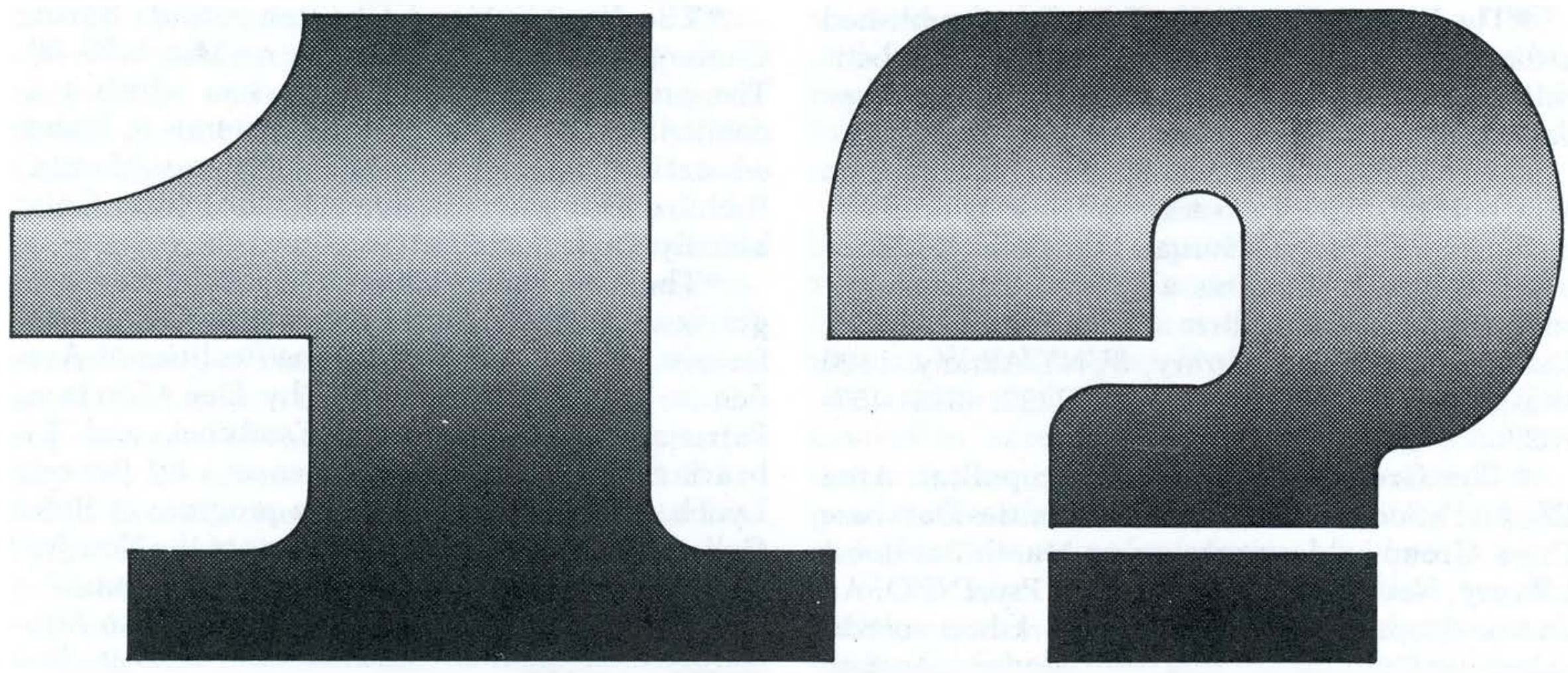

Ask 495 European publishers to standardize their serial bills to

\section{- one format}

\section{- one currency}

- one expiration date

Guess at their answers...

But once you concentrate your subscriptions with SWETS the miracle happens... one currency (US\$ or Can\$), one renewal date, invoice date(s) of your choice.
And with all these publishers... SWETS the key to reliable subscription handling and unrivaled ordering, claiming and paying procedures.

Why go direct or use many agents if SWETS offers a complete solution.

SWETS - a solid bridge between your library and European publishers.

Ask for more information. See coupon below. Thank you.

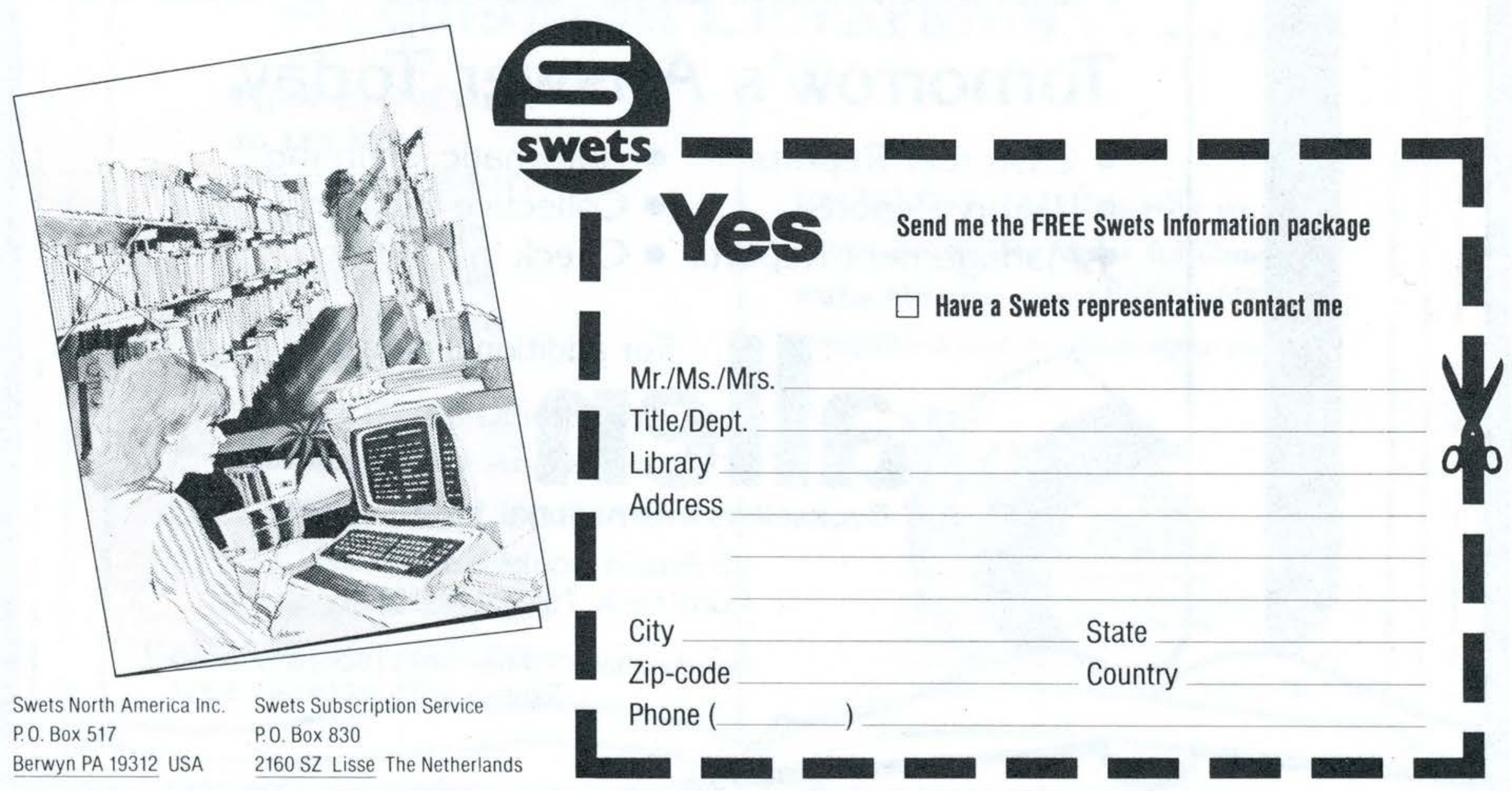

